\title{
Representaciones sociales de las
} enfermeras sobre su profesión: una revisión integrativa

\section{Social representations of nurses about their profession: integrative review Representações sociais do enfermeiro sobre sua profissão: uma revisão integrativa}

\author{
Yanna Gomes de Sousa Sousa ${ }^{1}$, Soraya Maria de Medeiros \\ Medeiros $^{2}$, Danielle Rezende Ferreira Ferreira ${ }^{3}$, Aline Dannyele \\ Souza de Oliveira Oliveira ${ }^{4}$, Marília Souto de Araújo ${ }^{5}$, Francisco \\ Arnoldo Nunes de Miranda Miranda ${ }^{6}$
}

\begin{abstract}
${ }^{1}$ Nurse. Nursing Master Rio Grande do Norte Federal University/UFRN. Natal (RN), Brazil. Correo electrónico: yanna_gomes@yahoo.com.br

${ }^{2}$ Nurse. Nursing Doctor. Post-graduation Program Professor. Nursing/Nursing departure. Rio Grande do Norte Federal University/UFRN. Natal (RN), Brazil. Correo electrónico: yanna_gomes@yahoo.com.br

${ }^{3}$ Nurse. Nursing Master Rio Grande do Norte Federal University/UFRN. Natal (RN), Brazil. Correo electrónico: danidantarii@yahoo.com.br

${ }^{4}$ Nurse. Nursing Master Rio Grande do Norte Federal University/UFRN. Natal (RN), Brazil. Correo electrónico: alinedanielee@hotmail.com

${ }^{5}$ Nursing Master Rio Grande do Norte Federal University/UFRN. Natal (RN), Brazil. Correo electrónico: mariliasarauj@yahoo.com.br

${ }^{6}$ Nurse. Nursing Doctor. Post-graduation Program Professor. Nursing/Nursing departure. Rio Grande do Norte Federal University/UFRN. Natal (RN), Brazil. Correo electrónico: fransarnoalfo@hotmail.com

Cómo citar este artículo en edición digital: Sousa, Y.G., Medeiros, S.M., Ferreira, D.R., Oliveira, A.D.S., Araújo, M.S. E Miranda, F.A.N. (2019). Representaciones sociales de las enfermeras sobre su profesión: Una revisión integrativa Cultura de los Cuidados (Edición digital), 23(53). Recuperado de http://dx.doi.org/10.14198/cuid.2019.53.20
\end{abstract}

Correspondencia: Yanna Gomes de Sousa Sousa. Rio Grande do Norte Federal University/UFRN. Natal (RN), Brazil

Correo electrónico de contacto: yanna_gomes@yahoo.com.br Recibido: 07/11/2018; Aceptado: 09/02/2019

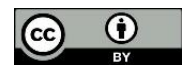

\begin{abstract}
An integrative literature review to identify the social representations of nurses about their profession. The literature searching was between September and November 2015 through the following databases: SCOPUS, PUBMED, Cochrane Library, ScienceDirect, Web of Science, CINAHL, and MEDLINE. The final sample consisted
\end{abstract}

of 05 articles. In the results, it was possible to identify characteristics of the publications and the social representations that nurses have of their profession. Thus, it was possible to know the differences in the perceptions of nurses about the social representations in their profession.

Keywords: Nursing, social representation, profession. 


\section{RESUMO}

Revisão integrativa da literatura para identificar as representações sociais do enfermeiro sobre sua profissão. A pesquisa bibliográfica ocorreu entre setembro e novembro de 2015, por meio dos seguintes bancos de dados: SCOPUS, PUBMED, Biblioteca Cochrane, ScienceDirect, Web of Science, CINAHL e MEDLINE. A amostra final consistiu em 05 artigos. Nos resultados, foi possível identificar características das publicações e das representações sociais que os enfermeiros possuem de sua profissão. Assim, foi possível conhecer as diferenças nas percepções dos enfermeiros sobre as representações sociais em sua profissão.

Palavras-chave: Enfermagem, representação social, profissão.

\section{RESUMEN}

Una revisión bibliográfica integradora para identificar las representaciones sociales de las enfermeras sobre su profesión. La búsqueda bibliográfica se realizó entre septiembre y noviembre de 2015 a través de las siguientes bases de datos: SCOPUS, PUBMED, Cochrane Library, ScienceDirect, Web of Science, CINAHL y MEDLINE. La muestra final consistió en 05 artículos. En los resultados, fue posible identificar las características de las publicaciones y las representaciones sociales que las enfermeras tienen de su profesión. De esta manera, fue posible conocer las diferencias en las percepciones de las enfermeras sobre las representaciones sociales en su profesión.

Palabras clave: Enfermería, representación social, Profesión.

\section{INTRODUCTION}

Considering the importance of the profession in the nursing context, it was decided to carry out an integrative review of the literature on the social representations that nurses have about their profession.

The Theory of Social Representations-TSR began in France in the 50s, when the social psychologist Serge Moscovici sought to understand how psychoanalysis, as a new expertise knowledge, was understood by the French society at that time. Social representations are a way of socially organized and shared knowledge which has a practical purpose and contributes to the creation of a reality common to a social group, called as knowledge of common sense or natural knowledge. The TSR is comprehensive because it uses concepts of attitudes, opinions, pictures and other, not excluding, but incorporating them, with relevance for social life as it indicates embodied cognitive processes in social interactions (Silva, Camargo \& Padilha, 2011).

The concept of profession came from the characteristics of the artisan type work developed in guilds or corporations of craftsmen in the Middle Ages, constituted in production units, training, and marketing of products. Although there was a division of labor, hierarchy and coordination and management of the production process activities, the producers were the owners of the instruments, had control over the process, the product and the pace of work, and in the production and reproduction of knowledge necessary for their work (Braverman, 1981). As a health profession, Nursing has been recognized since the second half of the nineteenth century, when Florence Nightingale added attributes to a health care field of activities developed for thousands of years by individuals or groups with different skills and different scenarios (Pires, 2009). As human science, Nursing is related to the field of knowledge, 
justifications, and practices of care for human beings that cover the areas of health and diseases. Regarding nursing care, the actions occur through personal, professional, scientific, ethical and political relationships.

Over the years, the nursing profession has achieved professional autonomy and technical-scientific and legal expertise, also contributing to the development of a civic practice. As a profession, it seeks for an identity, accepted by its peers, without sophistry and syllogisms, defining the nurse as what he is and not by what he does (Oguisso e Campos, 2013). As a profession, his role has been discussed by nurses and other health professionals. The discussion goes through the understanding of his importance in the health scenario and his potential to contribute to a new and more inclusive, holistic and critical paradigm in health (Antônio \& Denise, 2010)

This idea of building an identity for the profession means the attribution of meanings that support the understandings and interpretations that people have of themselves, the group to which they belong, or they consume. When we think of nursing or nurses, we evoke codes, images, representations that given a priori, they allow us to recognize people, abstract concepts, visualize places, landscapes and legitimize them as such. This perspective makes us think that the identity, at the same time is something changing, changed, revealed not only by the inexorable biological condition making the people as unique but also by the culture, profession, and lifestyle adopted (Oguisso \& Campos, 2013; Braverman, 1981). A research of nurses showed that social representations about the profession influence their choice for nursing and this profession is motivated by the desire to provide care to others, by expressing their ideas about the care demonstrating that the choice of their profession is based on criteria that emphasize not only the concepts of their professional area but also in personal attributes, the psychological aspects and especially in motivation (Backes, Backes, Stein \& Erdmann, 2010).

Considering this context, it is realized the need for a study showing the consensual knowledge of the nurses about their profession. We think that revealing these social representations, it enables an understanding of the psychosocial universe that involves professional regarding their profession. From this study, it aims to understand the process of organizing representations that the professionals build and are being created and socialized in their daily professional practice of the care process and the interactions between the various social actors in the nursing work. Thus, there is the urgent need to characterize the studies produced in this area to know its peculiarities. Based on these, this study aims to integrate literature studies produced on the social representations of nurses about their profession and know themConsidering the importance of the profession in the nursing context, it was decided to carry out an integrative review of the literature on the social representations that nurses have about their profession.

The Theory of Social Representations-TSR began in France in the 50s, when the social psychologist Serge Moscovici sought to understand how psychoanalysis, as a new expertise knowledge, was understood by the French society at that time. Social representations are a way of socially organized and shared knowledge which has a practical purpose and contributes to the creation of a reality common to a social group, called as knowledge of common 
sense or natural knowledge. The TSR is comprehensive because it uses concepts of attitudes, opinions, pictures and other, not excluding, but incorporating them, with relevance for social life as it indicates embodied cognitive processes in social interactions (Silva, Camargo \& Padilha, 2011).

The concept of profession came from the characteristics of the artisan type work developed in guilds or corporations of craftsmen in the Middle Ages, constituted in production units, training, and marketing of products. Although there was a division of labor, hierarchy and coordination and management of the production process activities, the producers were the owners of the instruments, had control over the process, the product and the pace of work, and in the production and reproduction of knowledge necessary for their work (Braverman, 1981). As a health profession, Nursing has been recognized since the second half of the nineteenth century, when Florence Nightingale added attributes to a health care field of activities developed for thousands of years by individuals or groups with different skills and different scenarios (Pires, 2009). As human science, Nursing is related to the field of knowledge, justifications, and practices of care for human beings that cover the areas of health and diseases. Regarding nursing care, the actions occur through personal, professional, scientific, ethical and political relationships.

Over the years, the nursing profession has achieved professional autonomy and technical-scientific and legal expertise, also contributing to the development of a civic practice. As a profession, it seeks for an identity, accepted by its peers, without sophistry and syllogisms, defining the nurse as what he is and not by what he does
(Oguisso e Campos, 2013). As a profession, his role has been discussed by nurses and other health professionals. The discussion goes through the understanding of his importance in the health scenario and his potential to contribute to a new and more inclusive, holistic and critical paradigm in health (Antônio \& Denise, 2010)

This idea of building an identity for the profession means the attribution of meanings that support the understandings and interpretations that people have of themselves, the group to which they belong, or they consume. When we think of nursing or nurses, we evoke codes, images, representations that given a priori, they allow us to recognize people, abstract concepts, visualize places, landscapes and legitimize them as such. This perspective makes us think that the identity, at the same time is something changing, changed, revealed not only by the inexorable biological condition making the people as unique but also by the culture, profession, and lifestyle adopted (Oguisso \& Campos, 2013; Braverman, 1981). A research of nurses showed that social representations about the profession influence their choice for nursing and this profession is motivated by the desire to provide care to others, by expressing their ideas about the care demonstrating that the choice of their profession is based on criteria that emphasize not only the concepts of their professional area but also in personal attributes, the psychological aspects and especially in motivation (Backes, Backes, Stein \& Erdmann, 2010).

Considering this context, it is realized the need for a study showing the consensual knowledge of the nurses about their profession. We think that revealing these social representations, it enables an understanding of the psychosocial universe 
that involves professional regarding their profession. From this study, it aims to understand the process of organizing representations that the professionals build and are being created and socialized in their daily professional practice of the care process and the interactions between the various social actors in the nursing work. Thus, there is the urgent need to characterize the studies produced in this area to know its peculiarities. Based on these, this study aims to integrate literature studies produced on the social representations of nurses about their profession and know them.

\section{METHOD}

This is an integrative literature review, summarizing the available studies on a given topic and leading the practice based on scientific knowledge (Souza, Silva \& Carvalho, 2010). This method contributes to the deepening of knowledge about the investigated object, showing the conclusions of the literature on a particular phenomenon, as well as identifying the gaps in knowledge about the phenomenon under study (Whittemore \& Knafl, 2005).

The following steps were followed to operationalize this review: selection of the problem or research question; literature search, including the definition of inclusion and exclusion criteria of the articles; evaluation of data to establish the information to be extracted from the selected articles; interpretation of results; synthesis of data and presentation of the review (Crossetti, 2012).

The following question was formulated: "What is published in the scientific literature of nursing, relating the social representations of nurses about their profession?".
The literature search took place between September to November 2015, through the use of a proxy licensed by the Federal University of Rio Grande do Norte (www.capes.ufrn.br/ porta 3128), accessed by Capes journals website (http://wwwperiodicos-capes-gov-

br.ez18.periodicos.capes.gov.br/) by the following databases: SCOPUS (Elsevier), National Library of Medicine-PUBMED, Cochrane Library, ScienceDirect (Elsevier), Web of Science (Main Collection-Thomson Reuters Scientific), Cumulative Index to Nursing and Allied Heath LiteratureCINAHL and Medical Literature Analysis and Retrieval System Online-MEDLINE Complete (EBSCO).

The descriptor $1 \#$ nursing with the keywords $2 \#$ social representation and $3 \#$ profession were used to search the databases. The use of two keywords is justified by the fact of not having found specific descriptors (social representation and profession). The crosses were performed using the Boolean AND operator: 1\# AND 2\# AND 3\#.

In each database, an uncontrolled search was conducted to identify a larger number of studies and also because the crossing was not done with descriptors only.

The inclusion criteria were full articles available on selected databases and articles that address the social representations of nurses about their profession. Editorials, letters to the editor, abstracts, expert opinions, correspondence, reviews, book chapters, theses, and dissertations were excluded.

The studies were pre-selected with a close reading of the titles and abstracts to identify if they were related to the guiding questions of the review, and the adopted inclusion and exclusion criteria. Then, the repeated articles in databases were excluded, and text 


\section{Cultura de los Cuidados}

reading was carried out in full. For the analysis and extraction of data from publications, a script with the following information was elaborated: a publication of the identification, location of the study, objective and results.

FIGURE 1: Summary of the data extraction process. Natal, Brazil, in 2015. After reading the articles, the data were described and presented in a table

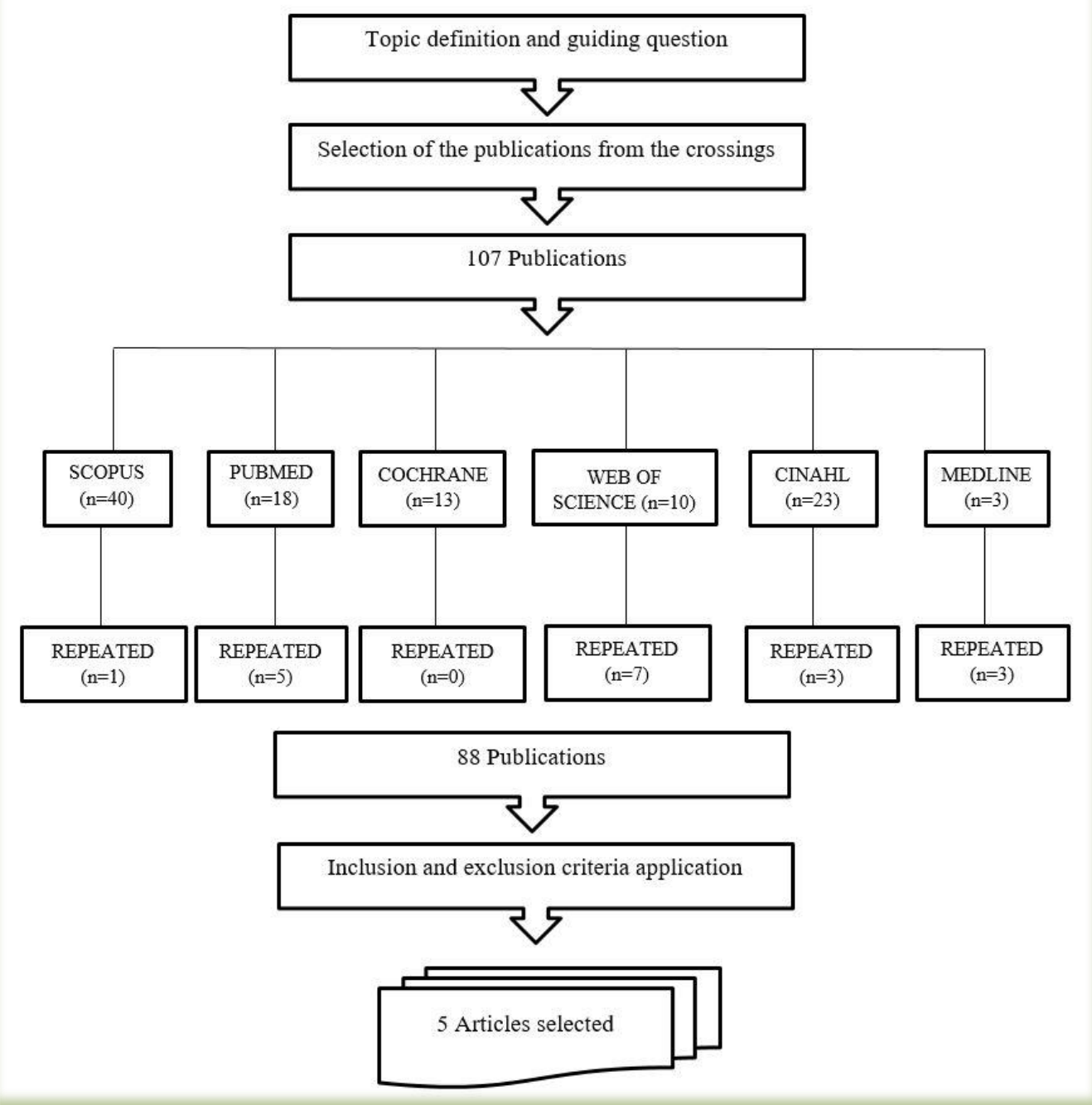

\section{RESULTS}

On 107 articles identified, 52 (48.6\%) were included in the first selection (title reading and abstract). In those selected, 19 (36.5\%) were excluded because they are repeated in the databases. Thus, 33 articles $(63.4 \%)$ were elected to read in full. Thus, the final review sample was composed of five (5) studies.

Table 1: below shows the consolidated of the studies included in the review, representing the essence for the preparation of results, discussion and conclusions regarding the studies produced on the social 
representations of nurses about their profession. The results showed that in the objectives, the studies vary in their understanding of social representations about the meanings of nursing as a profession.

\section{TABLE 1: Characterization of articles according to year/databases, title, authors, objective, and results. Natal, Brazil, in 2015}

\begin{tabular}{|c|c|c|c|c|c|}
\hline Article & Year/Databases & Title & Authors & Objective & $\begin{array}{c}\text { Results } \\
\text { Social representations of } \\
\text { nurses about their } \\
\text { profession }\end{array}$ \\
\hline A1 & LILACS, 2010 & $\begin{array}{l}\text { Current } \\
\text { nursing } \\
\text { dynamics in } \\
\text { Portugal: the } \\
\text { representatio } \\
\text { n of nurses. }\end{array}$ & $\begin{array}{l}\text { Felismina } \\
\text { Rosa } \\
\text { Parreira } \\
\text { Mendes: } \\
\text { Maria de } \\
\text { Fátima } \\
\text { Mantovani }\end{array}$ & $\begin{array}{l}\text { To identify the } \\
\text { representations } \\
\text { of the Portuguese } \\
\text { nurses about the } \\
\text { current dvnamics } \\
\text { of the profession } \\
\text { references to } \\
\text { their evolution } \\
\text { and prospects of } \\
\text { nursing. }\end{array}$ & $\begin{array}{l}\text { The meanings in the self- } \\
\text { image are insenarable and } \\
\text { are closelv linked to the } \\
\text { social rebresentations of the } \\
\text { profession and non- } \\
\text { recognition of their daily } \\
\text { experience. }\end{array}$ \\
\hline A2 & LILACS, 2005 & $\begin{array}{l}\text { Alteritv in } \\
\text { nursing } \\
\text { relationships. }\end{array}$ & $\begin{array}{l}\text { Ana } \\
\text { Cláudia } \\
\text { Giesbrecth } \\
\text { Puggina: } \\
\text { Maria Júlia } \\
\text { Paes da } \\
\text { Silva }\end{array}$ & $\begin{array}{l}\text { To identifv the } \\
\text { representation of } \\
\text { the "other" } \\
\text { (patient and } \\
\text { familv) in the } \\
\text { Nursing } \\
\text { relationship and } \\
\text { understand how } \\
\text { these } \\
\text { relationships } \\
\text { happen. }\end{array}$ & $\begin{array}{l}\text { Most of the nurses are } \\
\text { dissatisfied with their work } \\
\text { and the recognition of the } \\
\text { profession; they have } \\
\text { difficulty in communicating } \\
\text { with the patient without } \\
\text { demonstrating } \\
\text { authority. }\end{array}$ \\
\hline A3 & CINAHL, 2010 & $\begin{array}{l}\text { The center of } \\
\text { the } \\
\text { representatio } \\
\text { ns of nurses } \\
\text { about } \\
\text { nursing: the } \\
\text { proper role } \\
\text { of the } \\
\text { profession. }\end{array}$ & $\begin{array}{l}\text { Antonio } \\
\text { Marcos } \\
\text { Tosoli } \\
\text { Gomes I } \\
\text { Denize } \\
\text { Cristina de } \\
\text { Oliveira II }\end{array}$ & $\begin{array}{l}\text { To analyze the } \\
\text { structure of the } \\
\text { social } \\
\text { representation of } \\
\text { nursing and the } \\
\text { connection } \\
\text { relationship } \\
\text { between its } \\
\text { elements. }\end{array}$ & $\begin{array}{l}\text { In the organization of the } \\
\text { nursing social } \\
\text { representation, it was } \\
\text { observed that for the study } \\
\text { participants, the profession } \\
\text { has elements that place it in } \\
\text { a position to provide } \\
\text { answers to some of the } \\
\text { major health problems. }\end{array}$ \\
\hline A4 & SCOPUS, 1997 & $\begin{array}{l}\text { The nursing } \\
\text { and its } \\
\text { practice: the } \\
\text { thinking and } \\
\text { the living of } \\
\text { the nurses at } \\
\text { the hospital- } \\
\text { school São } \\
\text { Francisco de } \\
\text { Assis. }\end{array}$ & $\begin{array}{l}\text { Maria José } \\
\text { de Souza. } \\
\text { Suely de } \\
\text { Souza } \\
\text { Baptista }\end{array}$ & $\begin{array}{l}\text { To study the } \\
\text { social } \\
\text { representations } \\
\text { of nurses about } \\
\text { nursing and } \\
\text { professional } \\
\text { practice and how } \\
\text { they perform this } \\
\text { practice. }\end{array}$ & $\begin{array}{l}\text { Aspects were identified } \\
\text { such as the desire to help } \\
\text { others, the influence of the } \\
\text { family and previous } \\
\text { experience in the Health } \\
\text { area. Some of them would } \\
\text { like to study medicine. }\end{array}$ \\
\hline A5 & SCOPUS, 1997 & $\begin{array}{l}\text { The } \\
\text { understandin } \\
\text { g of nursing } \\
\text { ideas for the } \\
\text { transformatio } \\
\text { n of } \\
\text { professional } \\
\text { practice. }\end{array}$ & $\begin{array}{l}\text { Maria } \\
\text { Itayra } \\
\text { Coelho de } \\
\text { Souza } \\
\text { Padilha, } \\
\text { Nazaré } \\
\text { Otília } \\
\text { Nazario, } \\
\text { Marléa } \\
\text { Chagas } \\
\text { Moreira }\end{array}$ & $\begin{array}{l}\text { To understand } \\
\text { the social } \\
\text { representations } \\
\text { about nursing as } \\
\text { a profession } \\
\text { meaning. }\end{array}$ & $\begin{array}{l}\text { Nursing is perceived as a } \\
\text { profession of love to others. } \\
\text { One way to get close to God, } \\
\text { but also a challenge and } \\
\text { struggle for a better } \\
\text { profession. }\end{array}$ \\
\hline
\end{tabular}


About the characterization of the articles according to year/databases, title, authors, objective and results, there were five articles selected answering the research question, two (2) were in LILACS database, two (2) in SCOPUS, and 1 (one) in CINAHL.

According to the characteristics of each study, we can observe that the articles mentioned several social representations of the nursing profession such as current dynamics of the profession, the desire to help the other, the influence of family, previous experience in health care, the recognition of the profession, able to provide answers to some of the main health problems and as a profession of love for others and a way to get close to God.

\section{DISCUSSION}

\section{Representations of nurses about the profession}

Social representations are ways of knowledge guided by communication and understanding of the social, material and ideological context where we live, as cognitive elements (images, concepts, categories, theories), but not reduced only to cognitive knowledge. They are social phenomena to be understood from their production context, that is, from the symbolic and ideological functions they serve, and the forms of communication (Vala \& Monteiro, 2002)

Not only the scientific theories feed the social representations, but also the great cultural axes of formalized ideologies, experiences and everyday communications (Collière, 1989).

The study of social representations of nurses in their profession can provide very useful information in the context of research, and it could be the knowledge of the professional and scientific community in an educational context about their profession.

In recent times, nursing lives historical conflicts and challenging moments. The historical conflicts are based on in the care carried out primarily by the family and, more specifically, by the mother, as a direct way of maintaining the individual and collective life going through the various historical defining moments of the paradigms of our civilization (Porto \& Amorin, 2010)

The foundations at the beginning of the nursing profession according to Florence Nightingale were focused on normative aspects and not in technical and scientific knowledge, ruled on empirical knowledge, and closely linked to charity and the biomedical model.

Exercised in a wide variety of contexts, now nursing includes the care of the physical and organic needs, sometimes the psychological, emotional and spiritual needs, with an emphasis on human subjectivity (Antônio \& Denise, 2010), achieving its more effective role to its essence, with human care as its main focus.

The reinterpretation of nursing as a profession and science occurs under certain circumstances influenced by social, political, ideological and religious factors, with the challenge of understanding the process of organizing representations that the professionals have built, in the midst of this complex and multifaceted context, about the profession (Padilha, Nazario \& Moreira, 1997).

During our life, we build representations of what we know and/or experienced, even if that experience does not happen in full but partially.

The studies analysis of the results on the production of representations of nurses about the profession and their prospects of professional practice aims at the biomedical 
model to care and a more comprehensive view of the human being, as new possibilities to the profession that emerged in everyday practice.

The prospects for the profession guide to the employability, career and entering the profession at various levels of power, corroborating the expectation of appreciation and recognition that nursing professionals want in their daily practice. These characteristics are also directly linked to the nurses' ability to demonstrate the socio-economic importance of the profession through the delimitation of socially important actions, necessary and unique to their professionality (Antônio \& Denise, 2010).

In the selected studies, social representation of the profession was also associated with the construction of care in nursing as their work object. Care is seen as the profession identifier held from specific health or potential needs, characterized by professional expertise and ability to problem formulation and application of therapeutic care intervention, by its technical and art in its performance.

Caring begins, develops and ends in the person and with the person who becomes the momentary object of this action, but also transcends it, ensuring its extension to the community. It is for people and in people that the nursing professional works (privileged work object), and, for this, this action must be fully known, from its moral and social reasons until their objective resulting in therapeutic terms, that is, in their epistemology (Leopardi, Glebcke \& Ramos, 2001).

Care also runs through the issue of nurses' professional autonomy. In the process, it allows the possibility of reviewing the nursing as a profession, from its historical tradition, as well as linking with other scientific areas, a modern exercise of interdisciplinary.

Understanding the representations of nursing staff about their profession allows knowing the real and symbolic world that is present in the development of nursing practice every day.

\section{CONCLUSION}

This study allowed understanding the main social representations that permeate the nursing profession. The findings of this study revealed differences in the perceptions of nurses about the social representations in the profession.

Thus, to analyze the selected studies, the current dynamics of the profession, the desire to help the other, the influence of the family, previous experience in health care, and the recognition of the profession provide answers to some of the major health problems and also as a profession of love for others a way to get close to God. It is concluded that the representation of nursing for the nurses has multifaceted signs and meanings, complex with some unspecific and other elements important for the development of the profession.

\section{REFERENCES}

- Antonio, M.T.G. \& Denize, C.O. (2010). O núcleo central das representações de enfermeiros acerca da enfermagem: o papel próprio da profissão. Rev. enferm. UERJ, 18(3), 352-8. Recuperado de http://www.facenf.uerj.br/v18n3/v18n3a03.pdf.

- Backes, D.S., Backes, M.T., Stein, S.H.C.H. de. \& Erdmann, A.L. (2006). Principais razões que motivam os candidatos de nível técnico a uma vaga na profissão de Enfermagem. Esc. Anna Nery, 10(1), 75-80. Recuperado de http://dx.doi.org/10.1590/S1414$\underline{81452006000100009}$.

- Braverman, H. (1981). Trabalho e capital monopolista: 
a degradação do trabalho no século XX. Rio de Janeiro: Zahar.

- Collière, M.F. (1989). Promover a vida. Lisboa (Po): Sind. dos Enfermeiros Portugueses.

- Crossetti, M.G.O. (2012). Revisão integrativa de pesquisa na enfermagem: o rigor científico que lhe é exigido. Rev Gaúcha Enferm, 33(2): 8-9. Recuperado de http://www.scielo.br/pdf/rgenf/v33n2/01.pdf.

- Jodelet, D. (1984). La representación social: fenómenos, concepto y teoría. In Moscovici, S. La Psychologie Sociale. Paris, PUF.

- Leopardi, M.T., Glebcke, F.L., Ramos, F.R.S. (2001). Cuidado: objeto de trabalho ou objeto epistemológico da enfermagem? Texto \& Contexto Enferm, 10(1), 32-49.

- Oguisso, T. \& Campos, P.F.S. (2013). Por que e para que estudar história da enfermagem? Enfermagem em Foco, 4(1), 49-53. Recuperado de http://webcache.googleusercontent.com/search?q= cache:8EONVxW6vOMT:revista.cofen.gov.br/inde x.php/enfermagem/article/download/503/193+\&cd $=1 \& h l=p t-B R \& c t=c l n k \& g l=b r$.

- Padilha, M.I., Coelho, S., Nazario, N.O. \& Moreira, M.C. (1997). A compreensão do ideário da enfermagem para a transformação da prática profissional. R. Bras. Enferm, 50(3), 307-322. Recuperado de http://dx.doi.org/10.1590/S0034-

\section{2.}

- Pires, D. A. (2009). Enfermagem enquanto disciplina, profissão e trabalho. Rev. bras. Enferm, 62(5), 739-744. Recuperado de http://dx.doi.org/10.1590/S003471672009000500015 .

- Porto, F. \& Amorin, W. (2010). História da Enfermagem: Identidade, profissionalização e símbolos. São Caetano do Sul, SP: Yendis Editora.

- Silva, S.E.D da., Camargo, B.V.,\& Padilha, M.I. (2011). A teoria das representações sociais nas pesquisas da enfermagem brasileira. Rev. bras. Enferm, 64(5), 947-951. Recuperado de http://dx.doi.org/10.1590/S0034$\underline{71672011000500022 .}$

- Souza, M.T., Silva, M.D. \& Carvalho R. (2010). Revisão integrativa: o que é e como fazer. Einstein, 8(1), 102-6. Recuperado de http://www.scielo.br/pdf/eins/v8n1/pt 1679-4508eins-8-1-0102.pdf.

- Vala, J. \& Monteiro, M.B. (2002). Psicologia Social. Lisboa: Fundação Calouste Gulbenkian. 5. ㄹ Edição.

- Whittemore, R. \& Knafl, K. (2005). The integrative review: updated methodology. J Adv Nurs, 52(5), 546-53. Recuperado de http://dx.doi.org/10.1111/j.1365-2648.2005.03621.x. 